\title{
IMPLICATURES IN FICTION TEXTS
}

Farida B. Sitdikova ${ }^{1}$

Guzel R. Eremeeva ${ }^{2}$

Ekaterina V. Martynova ${ }^{3}$

Abstract: The article considers implicatures of utterances. An implicature is information complex which is literally (verbally) unexpressed and which can be elicited as a result of extracting the meaning using background knowledge of recipient, context and situation. Formation and understanding the meaning of an utterance is the process of extracting implied meaning which is formed by interaction of linguistic units with constituents of cognitive environment. An utterance therefore can be considered as a speech stimulus involving the knowledge from cognitive environment to form the meaning of the utterance. Extracting the meaning is (that is, eliciting an implicature) is important for communicion. The purpose of the research was to study various aspects of implicatures: the way of extracting the meaning, describing different types and obtaining statistical data of different types implicatures usage. In particular, our research demonstrates statistical prevalence of contextual implicatures. The results of the paper can be of some interest for experts in linguopragmatics and psycholinguisics.

Keywords: language, linguistics, research, implicature, utterance, implicitness, implicit meaning, contextual implicatures, common communicative implicatures.

\section{Introduction}

During the recent decades significant changes have taken place in

\footnotetext{
${ }^{1}$ Kazan Federal University.e-mail: farida7777@yandex.ru. Tel. +7 (905) 025576.

${ }^{2}$ Kazan Federal University.e-mail: farida7777@yandex.ru. Tel. +7 (905) 025576.

${ }^{3}$ Kazan Federal University.e-mail: farida7777@yandex.ru. Tel. +7 (905) 025576.
} 


\section{Periódico do Núcleo de Estudos e Pesquisas sobre Gênero e Direito Centro de Ciências Jurídicas - Universidade Federal da Paraíba V. 8 - No 04 - Ano 2019 - Special Edition ISSN | 2179-7137 | http://periodicos.ufpb.br/ojs2/index.php/ged/index}

the studies of linguistic phenomena from predominantly grammatical approach researches shifted to the complex one including methods from psycholiguistics, sociolinguistics, ethnoliguistics, cognitive linguistics, and liguopragmatics which is one of the most promising fields of contemporary linguistics.

Linguopragmatics studies a wide range of issues, but our research focuses on interpretation of utterances by a recipient and meaning drawing during a communication act. The presence of implicit meaning in an utterance is one of the major features of verbal communication.

According to the Sperber and Wilson's theory of relevance [1], formation and understanding the meaning of an utterance is the process of drawing or interpretation of meaning. The interpretation proceeds in a number of steps; each step is associated with implication or in other words each step of meaning formation involves an implied meaning. This is not clearly expressed but some utterances have an implied meaning which is formed by interaction of linguistic units with constituents of cognitive environment.
An utterance itself can be considered as a speech stimulus involving the knowledge from cognitive environment to form meaning [2].

In the following dialogue

A: Where's Bill?

B: There's a yellow VW outside Sue's house.

B's reply is a relevant answer to A's question: if Bill has a yellow VW car, he may be in Sue's house [3].

Consider the following example from Tatar fiction:

- Ul minga sezne senglem didde.

- Aning seglese ya tumagan, ya aida... [4].

- He told me you are his sister.

- His sister either hasn't been born or is on the Moon...

From the highlighted utterance we can come to the conclusion that the above mentioned sister does not exist. This hidden meaning of the utterance which is not expressed verbally but can be understood by communicants from cognitive environment, context and situation is called the implicature. 


\section{Periódico do Núcleo de Estudos e Pesquisas sobre Gênero e Direito Centro de Ciências Jurídicas - Universidade Federal da Paraíba V. 8 - No 04 - Ano 2019 - Special Edition ISSN | 2179-7137 | http://periodicos.ufpb.br/ojs2/index.php/ged/index}

\section{Methods}

Our research based on Tatar fiction texts is focused on implicatures. An implicature is an implied meaning of an utterance or literary (verbally) unexpressed information complex which can be elicited as a result of meaning drawing (implication) using additional background knowledge, the situation and the context. The aim of the investigation was to study various aspects of implicature: implicature drawing, classification and some statistical data of their usage.

In this paper we have made use of component analyses and description methods. As language examples we have used extracts from Tatar fiction containing different kinds of implicatures.

\section{Results}

For efficient communication act a recipient should be able to elicit the concrete and contextual meaning and implicature from an expressed utterance. It should be noted that eliciting the implicature from an utterance is not the only condition. Initially, the postulates drawn by language philosopher Grice should be followed. These are the principles of Cooperation, Quantity, Quality, Relation, and Technique which are the essential conditions for succeeded communication act [5]. Nevertheless, implicature eliciting by a recipient remains the major condition.

The process of eliciting the concrete and contextual meaning and implicature can be shown in the following example: Americaga... kaichan da bulsa kilep chigip alirmin digen uy bashima kerep chikmadi. Bezde mekal' bar - yurgagina karap ayak suzasing [6]. It never occurred to me that I might travel to America. We have a saying - stretch your legs according to the coverlet.

The utterance semantics can be understood by presuppostions, which are both linguistic knowledge (linguistic presuppositions) and general knowledge (extralinguistic presuppositions, for example America). The utterance implicature is the following: The character of the story never though that she would travel to America because she could never afford it.

As for the "implicature" term the notion goes back to the works by Grice who divided implicatures into the conventional (drawn from meaning of 
words used in an utterance) and communicative ones (drawn from the knowledge of context) [7].

In his book "Logic and conversation" Grice wrote that one utterance can correspond to more than one implicatures. Implicature drawing depends both on objective factors (presence of certain background knowledge) and the subjective ones (recipient's ability to draw implicatures).

Implicatures can be divided according to various principles: on type of information being transmitted; the way of implicature formation; implicature role in the structure of utterance global meaning; implicature relations with other components of meaning in an utterance. We follow the classification proposed by V.Komissarov who classifies implicatures according to the correlation between the general content of an utterance and its drawn implicit meaning [8].

We completely share V. Komissarov's view classifying implicatures into common communicative and contextual that corresponds to two kinds of implicitness: 1) common communicative ones which are relates to the linguistic content of an utterance and 2) contextual, related to individual context content.

The common communicative implicature can be shown in the following example: Ker, pnimayete li,biologiyage. Beraz tegelairek keshese (director imen barmagi belen chigeden estarak bashina tukip kursette), no kak specialist - kechle [9]. ... You can enter the Biology lesson. The teacher is a bit strange (the Headmaster tapped his index finger slightly above the temple), but very strong as a specialist. In any context tapping or twisting one's index finger by temple indicates describing a strange, odd person. Thus, common communicative implicatures retain their implicit meaning regardless a context or situation.

The second type of implicatures is the contextual one. Drawing the contextual implicatures can be explained with the fact that in any concrete context any utterance can acquire an additional meaning as in the following example:

Kazanga yerakmi song?

Yerak tugel! Ike segat'tan anda bulabiz.

Ike sagat'? 
Annan da alda barip bulmiy. Raspisaniye [10].

Are we far from Kazan?

Not that far. We'll arrive in two hours.

Two hours?

It won't be possible to arrive earlier. The schedule.

The implicature from the underlined utterance is drawn using the background knowledge: The train have to observe the schedule.

\section{Discussion}

The correlation between common meaning and implicature in an utterance can be classified into three types: real (objective), logical, and conventional. The conventional type of correlation V.Komissarov further divides into symbolic, figurative, and etiquette [11].

The implicit meaning often bases on real (objective) relations between objects which helps to identify the equation between the described and implied situations. The participants of communication identify this equation basing on their personal experience, i.e. the cognitive base. For example, turning a key means locking or unlocking a door, slamming the breaks means stopping a car.

Explicit and implicit meanings can also have logical relations allowing the communication participants drawing logical conclusions from an utterance. Consider this example:

Mine yugalttingmi? - dide yegget.

Yugaltir echen, bashta tabarga kirek, - dide kiz. [12].

Did you lose me? - asked the guy.

Before losing you have to find first, - answered the girl.

The implicature from this funny utterance is that a young lady states that she has not missed or thought of that young man.

The conventional relations between implicit and explicit meanings can exist only provided that an utterance is used to denote a situation which due to various reasons can not be indicated directly.

As it has been already mentioned above, the conventional implicatures can be symbolic, figurative, and etiquette. The symbolic implicatures a frequently associated with human behavior, gestures, mimics i.e. kinemics specific to 


\section{Periódico do Núcleo de Estudos e Pesquisas sobre Gênero e Direito Centro de Ciências Jurídicas - Universidade Federal da Paraíba V. 8 - No 04 - Ano 2019 - Special Edition ISSN | 2179-7137 | http://periodicos.ufpb.br/ojs2/index.php/ged/index}

every linguistic and cultural community. For example, nodding or shaking one's head from side to side for a Russian speaker means agreement or disagreement while for a Bulgarian speaker these gestures have the opposite meanings. The example of a symbolic implicature: Mirvali kizga iyak kakti da Shamsiyagayanga tekelde [13]. Mirvali nodded to the girl and stared at Shamsiyagayan. (Nodding a head in many cultures mean agreement, compliance or confirmation).

Implicatures can emerge basing on the figurative meaning of an utterance which can be drawn from communicative situation and context. Consider a language example: Uze ezgech echkerten sagish beggep ani Balkis da tabriklade. Mena bit, Balkis monda annan aldanrak kilgen ide. A Narkisneng kilgane nibari alti-jide ai. Cartochka ber aska kumelep kalsa, ani berkem ezlap kalmi inde [14]. Overcoming the internal pain, Balkis also congratulated her. In fact, she had come here a lot earlier. And Narkis arrived only six-seven months ago. But if the card is lodged in a drawer bottom, no one will find it. The card, lodged at the bottom of the card file box, symbolizes the fate of an elderly teacher who could not create a family in time.

Consider an example of etiquette implicatures. In certain situations due to ethical considerations the participants of communication have to use euphemisms because literal expressions of the meaning are impossible. For example, talking about death many nations use various euphemisms like in the following example: Mansurni yuldan alirga digen nikli kararga kilde Saet. Isuli ber gene... "Ojmahka ozatu" [15]. Sait made a decision to get Mansur out of his way. There was only one way... "To send him to Paradise".

\section{4. Summary}

Apart from the Grice's postulates for effective communication act, the implicature drawing by a recipient is the major condition. Perception of the utterance means that a recipient retrieves not only the meaning of linguistic units but also using situation, context, and cognitive base a recipient elicits literary unexpressed additional information, i.e. implicature.

In our studies on linguistic examples from Tatar fiction 200 
implicatures of different types have been considered. The investigation results including the quantitative ones are listed in conclusions.

\section{Conclusions}

1. The implicatures can be classified into common communicative and contextual ones. Our research has shown statistical prevalence of contextual implicatures. Of 200 implicatures selected from original texts the contextual implicatures were $73 \%$ while common communicative ones were only $27 \%$.

2. According to the correlation between the common meaning and the implied one the implicatures can be divided into the objective, logical, and conventional (consisting of symbolic, figurative, and etiquette ones).

3. Our investigation results have shown that most of the selected implicatures were the figurative ones (53\%) which apparently can be explained by the fact that the studies were carried out using the texts from fiction prose.

4. The second prevailing implicatures were the logical ones
(28\%), then symbolic (8\%), objective (16\%), and etiquette ones (5\%).

\section{Acknowledgements}

The work is performed according to the Russian Government Program of Competitive Growth of Kazan Federal University.

\section{Bibliography}

D.Sperber, D.Wilson.: Relevance. Blackwell, Oxford, 2003.

A,V.Kashichkin. Implitzitnost V kontexte perevoda.: dis. ... kand. filol. nauk: 10.02.20: Москва, Р.9, 2003.

S.G.Levinson: Pragmatics. Cambridge University Press, Cambridge, 1983, P.102.

N.Gimatdinova. Ikebezge de avir. Kazan, 2002. . P. 317.

H.P.Grice. Logic and conversation. In: «Syntax and semantics», v. 3, ed. by P. Cole and J. L. Morgan, N.Y., Academic Press, 1975.

F.Yarullin. Yarali yazmishlar. Kazan, Ruhiat, 2000. P.182. 
Periódico do Núcleo de Estudos e Pesquisas sobre Gênero e Direito Centro de Ciências Jurídicas - Universidade Federal da Paraíba

V. 8 - $\mathrm{N}^{\mathrm{o}} 04$ - Ano 2019 - Special Edition

ISSN | 2179-7137 | http://periodicos.ufpb.br/ojs2/index.php/ged/index

H.P.Grice. Logic and conversation. In: «Syntax and semantics», v. 3, ed. by P. Cole and J. L. Morgan, N.Y., Academic Press. P.43, 1975.

V.N.Comissarov. Sovremennoye perevodovedeniye. M., ETS.2002.

M.Mahdiev. Sailanma eserler. Kazan, Tatarstan kitap nashriati, 1996. vol.2. Frontoviklar. P.96.

A.M.Guilajev. Jomga ken, kich belen. Kazan, 19982. P.9.

V.N.Comissarov. Sopostavitelnoperevodcheskiy analiz implicitnogo smisla viskazivaniya// Linguisticheskie i metodicheskiye problemi prepodavaniya russkogo yazika kak nerodnogo: sb. Nauchn.trudov/AN SSSR, In-t yazikoznaniya; redactor A.M. Shakhnazarovich. M., 1991. P. 89-91.

N.Gimatdinova. Parly yalgiz. Kazan, 2003. P.103.

A.M.Guilajev. Jomga ken, kich belen. Kazan, 19982. P.26.
M.Mahdiev. Sailanma eserler. Kazan, Tatarstan kitap nashriati, 1996. vol.2. Frontoviklar. P. 187.

T.N. Galiullin. Taube. Kazan: Taтarstan kitap nashriyate. 1997. P. 137 